\title{
A novel case and review of paediatric Horner syndrome
}

\author{
George Moussa ${ }^{1} \cdot$ Jesse Panthagani ${ }^{1} \cdot$ Elizabeth Gavens ${ }^{1} \cdot$ Michael Singh $^{1} \cdot$ Sally Painter ${ }^{1}$
}

Received: 30 September 2019 / Accepted: 2 October 2019 / Published online: 15 May 2020

(c) The Royal College of Ophthalmologists 2020

\section{To the Editor:}

We present a novel presentation of Horner syndrome (HS) in a child after button battery (BB) ingestion (BBI). The BB impacted in the cervical oesophagus disrupting the ipsilateral sympathetic chain. Acute presentation of HS may include ptosis, miosis and facial anhidrosis.

A 1-year-old boy, with no medical or family history, attended with a 4-week history of sore throat, pyrexia, reduced intake, vomiting and a presumed swollen left upper eyelid, despite initial treatment with coamoxiclav for likely tonsillitis and chloramphenicol to the left eye.

Clinical assessment revealed persistent pyrexia, a left eye $3 \mathrm{~mm}$ ptosis with miosis but tolerating solid food. Pharmacological testing for HS with apraclonidine $1 \%$ caused a resolution of the ptosis and miosis after $20 \mathrm{~min}$, confirming an HS (Fig. 1a, b). A chest X-ray revealed a $23 \mathrm{~mm}$ BB lodged in the oesophagus at the level of the lower cervical spine (Fig. 2a, b).

Rigid oesophagoscopy revealed the BB lodged in the oesophageal wall with circumferential white scarring noted after removal. Post-operative thoracic computer tomography (CT) scan demonstrated para-oesophageal air, consistent with a perforation (Fig. 2c). This was managed conservatively - nil by mouth, nasogastric feeding and intravenous co-amoxiclav. After 10 months, the HS has completely resolved (Fig. 1c).

Aetiologies of HS in a paediatric population are summarised in Table 1. In children with acute dysphagia, unwitnessed foreign-body ingestion must be considered.

Investigation of BBI with MRI could be catastrophic due to magnetism of $\mathrm{BB}$. In five case series of 90 acquired

George Moussa

george.moussa@nhs.net

1 Birmingham Children's Hospital, Steelhouse Ln, Birmingham B4 $6 \mathrm{NH}, \mathrm{UK}$

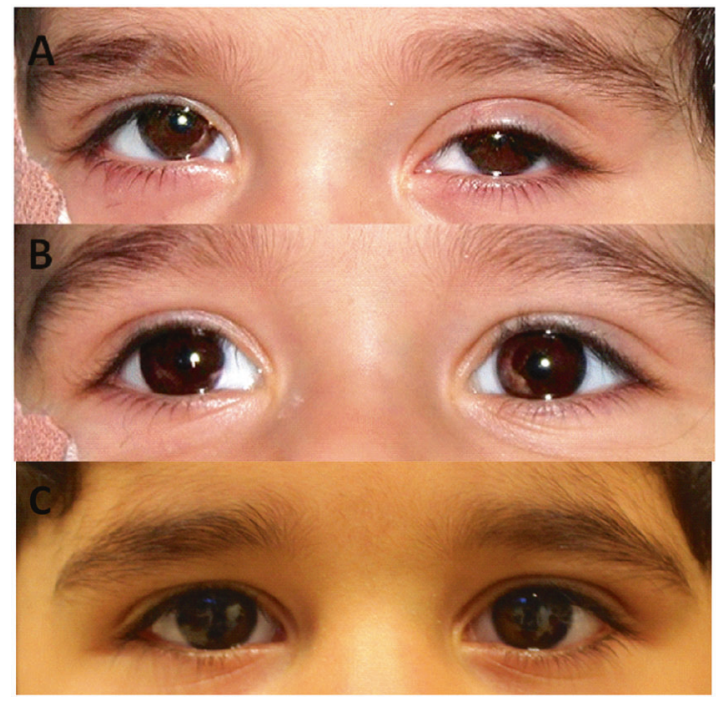

Fig. 1 a Before application of apraclonidine 1\%. Miosis left eye and partial ptosis. b Twenty minute post apraclonidine $1 \%$ instillation to both eyes. Reversal of ptosis, and mydriasis of left eye. c 10 months after initial presentation.
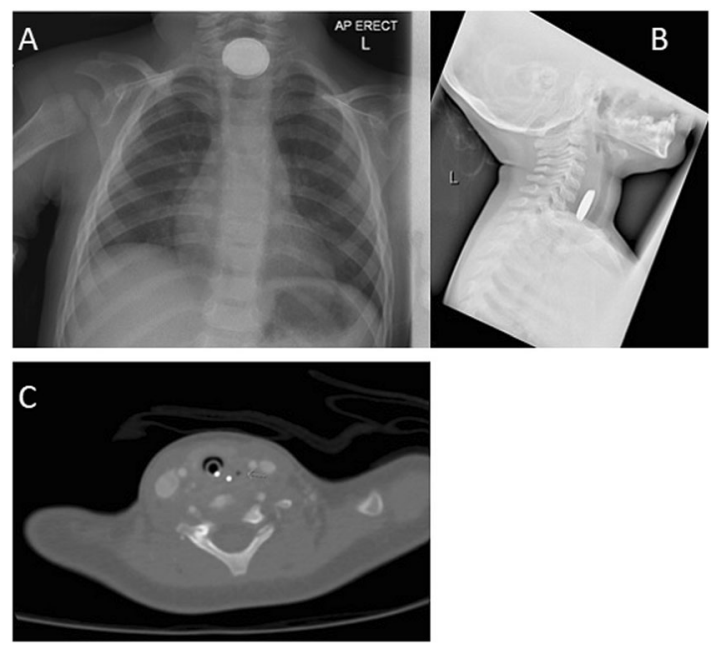

Fig. 2 a Antero-posterior chest X-ray revealing $23 \mathrm{~mm}$ button battery. Note the characteristic double rim of the battery. $\mathbf{b}$ Oesophageal impaction with button battery anterior to cervical vertebrae levels 5-7. c Inflammatory changes and air (arrow) within the pre-vertebral soft tissues in the mid-to-lower neck and posterior to the left lobe of the thyroid and between the left lobe of the thyroid and the left common carotid artery. 


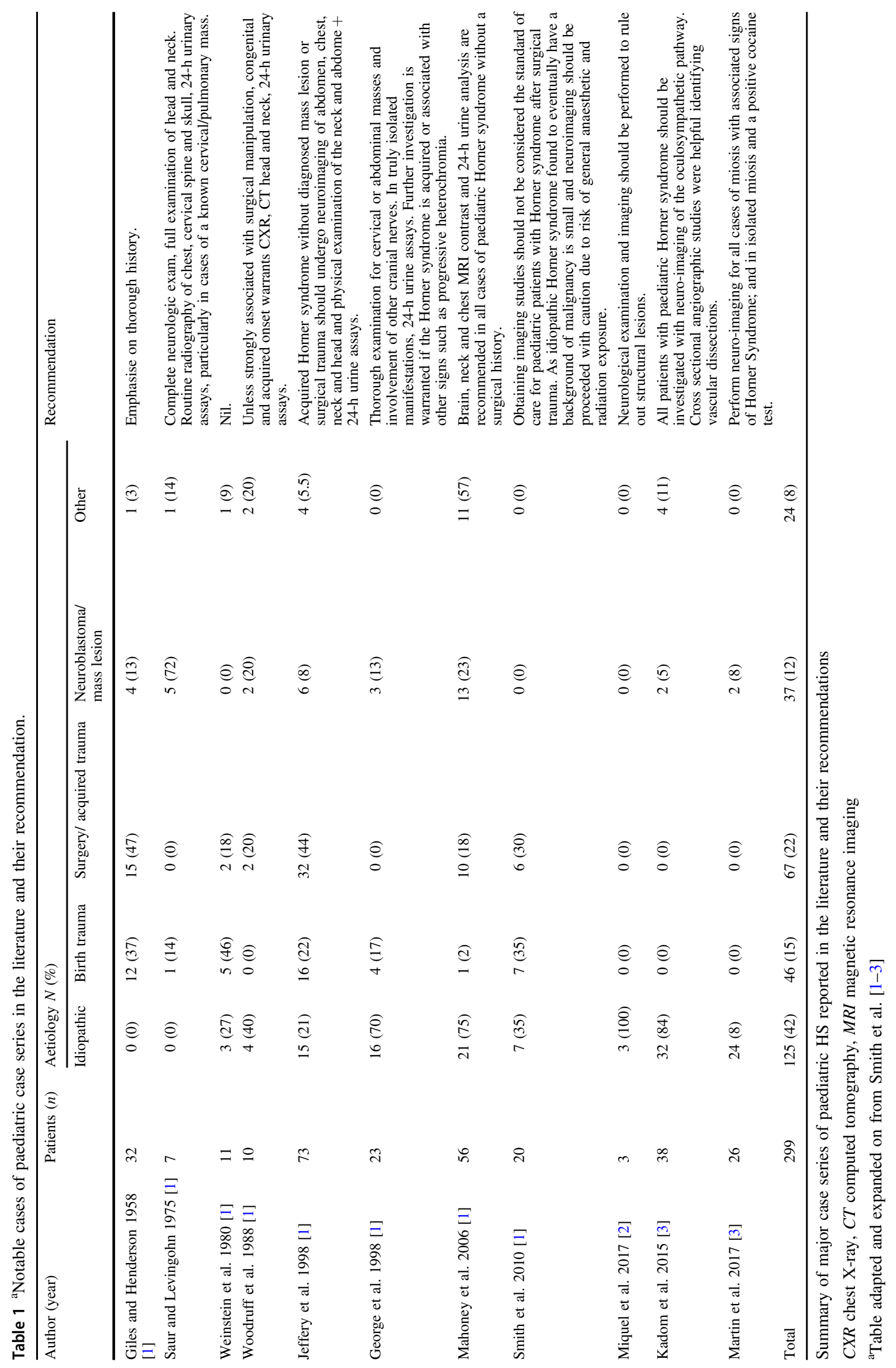


paediatric HS where MRI was clinically available, clinicians chose to exclusively investigate with MRI $63(70.0 \%)$, CT 8 (8.9\%), plain-XR 3 (3.3\%) or no imaging $8(8.9 \%)$ [1-3]. With a 6.7 -fold increase of BBI in 25 years [4], this unique presentation demonstrates the importance of plain-XR prior to MRI imaging, particularly in cases with a history of upper gastrointestinal symptoms.

BBI can result in tissue damage from several mechanisms: electrical discharge, pressure necrosis, leakage of alkaline content and metal toxicity. The caustic injury is generated from hydroxide radicals in the mucosa resulting from high $\mathrm{pH}$. Animal models have shown a rise in $\mathrm{pH}$ from 7 to 13 at the BB's negative terminal and necrosis of oesophageal lamina propria within $15 \mathrm{~min}$ of ingestion, with extension to the outer muscular layer within $30 \mathrm{~min}$ [5].

The National Capital Poisons Center cohort of BBI (8648 cases) reported death in 13/8648 $(0.15 \%)$ and a major morbidity in $73(0.8 \%)$ patients [6]. The major risks for these are BB diameter $>20 \mathrm{~mm}$, lithium cells (longer shelf life, increased voltage capacity and stability at cool temperatures) and oesophageal impaction [1].

In this case, the exact mechanism of injury to the sympathetic chain is unknown, however we presume that changes to the electrical environment, or associated inflammation disrupted conduction, which at 10 month follow-up, made complete recovery (Fig. 1c).

The administration of topical apraclonidine, in a paediatric setting, can cause central nervous system depression. National recommendations from the Royal College of Ophthalmologists have been published after this case, that advise against, for paediatric HS diagnosis: apraclonidine $1 \%$, apraclonidine $0.5 \%$ below 6 months of age and extra caution below 2 years of age. Monitoring should be for $2 \mathrm{~h}$ following administration. We report no drowsiness following close observation after administration.

\section{Compliance with ethical standards}

Conflict of interest The authors declare that they have no conflict of interest.

Publication consent statement The authors confirm that they have obtained informed consent for publishing this case including all photographs.

Publisher's note Springer Nature remains neutral with regard to jurisdictional claims in published maps and institutional affiliations.

\section{References}

1. Smith SJ, Diehl N, Leavitt JA, Mohney BG. Incidence of pediatric Horner syndrome and the risk of neuroblastoma: a populationbased study. Arch Ophthalmol. 2010;128:324-9. http://www.ncbi. nlm.nih.gov/pubmed/20212203.

2. Miquel J, Piyaraly S, Dupuy A, Cochat P, Phan A. Congenital cases of concomitant harlequin and Horner syndromes. J Pediatr. 2017;182:389-92. http://www.ncbi.nlm.nih.gov/pubmed/28038766.

3. Braungart S, Craigie RJ, Farrelly P, Losty PD. Paediatric Horner's syndrome: Is investigation for underlying malignancy always required? Arch. Dis. Child. 2019.

4. Varga Á, Kovács T, Saxena AK. Analysis of complications after button battery ingestion in children. Pediatr Emerg Care. 2018;34: 443-6. http://www.ncbi.nlm.nih.gov/pubmed/29369262.

5. Kramer RE, Lerner DG, Lin T, Manfredi M, Shah M, Stephen TC, et al. Management of ingested foreign bodies in children: a clinical report of the NASPGHAN Endoscopy Committee. J Pediatr Gastroenterol Nutr. 2015;60:562-74. http://www.ncbi.nlm.nih.gov/ pubmed/25611037.

6. Litovitz T, Whitaker N, Clark L. Preventing battery ingestions: an analysis of 8648 cases. Pediatrics. 2010;125:1178-83. http://www. ncbi.nlm.nih.gov/pubmed/20498172. 